\title{
The body as metaphor: digestive bodies and political surgery in Shakespeare's Macbeth
}

\section{Spicci}

J Med Ethics; Medical Humanities 2007;33:67-69. doi: 10.1136/jmh.2007.000257

The article aims to reconstruct the perspective of bodily pathology underpinning Shakespeare's Macbeth. In the play, Scotland's body politic is frequently depicted as a macro-system suffering from a complexional imbalance of digestive origins. More specifically, Scotland comes over as a huge stomach strangled by a carcinogenic foreign body in need of being "raze[d] out". Since traditional purgative drugs such as "rhubarb" and "cynne" turn out to be totally inefficient to cure the body of Scotland, the resolution to adopt a drastic medical measure becomes more than urgent. The conclusion of the play coincides with the most terrible form of political surgery: Shakespeare's reiterated use of verbs such as "pluck" and "purge", commonly used in Renaissance herbals and handbooks, suggests that Macbeth's physical body is suffering from a kind of "blockage", for which herbal treatments are no longer sufficient. Nothing less than a surgical operation is needed to "purge" the corrupt entrails of the State dominated by Macbeth's tyranny.

Correspondence to: Mauro Spicci, Dip. Scienze del Linguaggio e Letterature Straniere Comparate, Sezione di Anglistica, Piazza S Alessandro 1, 20123 Milano, Italy; spiccifam@alice.it he metaphor of the human body has been broadly exploited in western political discourse. In particular, adopting the human body as a model for the State has always coincided with the attempt to arrange political abstract "plurality" and to make it easily understandable: this statement seems to lie at the core of the most common versions of the corporeal allegory, such as Plato's psychocentric polis, Aristotle's organic political model and Saint Paul's vision of the Church as Christ's body contained in the first epistle to the Corinthians, all of which have strongly influenced the development of Western political thought. Because of its exegetic immediacy, the traditional metaphor of the body politic, originally coined by Plato and Aristotle, plays. In Coriolanus (1607), through the mise-enscène of the well-known Livian "fable of the belly", Shakespeare dramatises the old organological tradition, which finds its strongest upholder in John of Salisbury: the medieval author of Policraticus (1159) leads the traditional abstraction of the human body to perfection by idealising the basest among physiological functions-that is, the digestiveemunctory one-thus providing his readers with the "most ideologically pacificatory among the organic and hierarchical images of society" (my translation) (p22) $)^{2}$ ever formulated. Nevertheless, John of Salisbury's medieval version of the "fable of
$\mathrm{T}$ spreads in Elizabethan and Jacobean political treatises, and underpins many of Shakespeare's the belly" suggests a brand new conception of the human body, one whose subversive implications Shakespeare seems to have deliberately adopted and transformed into a cornucopia of dramatic meaning.

The author of Policraticus gives shape to a new paradigm of the human body, which, though persistently surrounded by a halo of luminous perfection (genuinely inherited from Platonic and Aristotelian psychocentrism, which depicts the body as a mere appendage to the luminous and almighty soul), is strongly affected by an estranging pathological dimension. In Menenius' "fable of the belly", collective cohesion-the hallmark of "healthy societies", as Plato defines them ${ }^{3}$-is menaced by the impending mutiny of the limbs, which can cause the complexional imbalance of the whole political organism. Public welfare-this seems to be the hidden ideological scaffolding of Policraticus - though never overtly questioned or subverted, is a highly problematic matter: rather than being naturally inscribed in the matrix of the body politic, it results from a form of mutual agreement, resting on the fact that the parts recognise the stomach as the "king" of the whole body. Even though the risks of political fragmentation are averted, Menenius' well-known apologue suggests the "threefold figural horizon of the theory of the body politic: essentially the symbolical horizon of political anatomy, political pathology and political therapeutics" (my translation) (ppl19-20). ${ }^{4}$

Political pathology - a set of figural dispositions that interpret the functioning (and consequently the misfunctioning) of the body politic from a merely pathological perspective-is a long-established rhetorical and ideological background in Shakespeare's time, and as such it is plainly exploited by Shakespeare in a number of plays; but I shall show that in the modern age, something new-political surgery-ominously undermines the figural stability of the body politic theory and tries to replace traditional remedies as the unique means to heal the sickly body politic.

The tragedy of Macbeth-with its bloody portrait of a "disjoint[ed]" universe where the stability of

iThe idea of the perfect functioning of the human body has given birth to a number of different figural and metaphorical traditions (for example, the theory of the body politic; the analogy of macrocosm/microcosm) that are sustained by the idea that it is possible to draw analogies between the structure of the human body and that of more abstract and symbolical "bodies" such as the State or the Church. An analysis - both diachronic and synchronic - of the relationships between bodily metaphors and Shakespeare's dramatic experimentation can be found in my article The dialectics of self-anatomy. 
the body politic is invalidated by the reign of an illegitimate tyrant-fully pertains to the antique figural tradition of bodily political metaphors. However, it also reinforces the pathological perspective already implied-as we have seen-in John of Salisbury's version of the "fable of the belly". If, on the one hand, the massive recurrence of the semic group linked to "digestion" is enough to justify the adoption of a medical hermeneutical perspective, it is likewise true that the numerous references to the semantic areas of "eating" and "drinking" cast a new light on the play's pathological dimension. In fact the progressive accumulation of images of difficult, even "unnatural", digestive processes actually makes it possible for the body politic in Macbeth to be transformed into a huge, sickly human body in want of medical cure.

Banquo is the first character to establish a logical relation between the quality of his diet and his precarious state of health. Being rapt and flattered by the Weird Sisters, Banquo wonders:

\section{BANQUO: Have we eaten on the insane root That takes the reason prisoner?ii (act 1, scene 3, lines 82-3)}

Banquo refers to a chimerical "root", which can cause "insanity" and trap the reason (namely Aristotle's rational part of the soul) in a condition of pathological captivity. But if we apply Banquo's words to the body politic, their meaning appears to be even more sinister: the wicked root can affect reason because the stomach does not do its duty. In Renaissance physiology, "together with its corollary organs of digestion", the stomach performs "the discrimination of dross from nutrition, of good from bad" (p244). ${ }^{6}$ This figuratively ethical function makes it very similar to a king, "the vital centre of a vast [political] system of food preparation and distribution" (p247). ${ }^{6}$ The pronoun "we" used by Banquo shapes a political community whose individual components either are not able to feed themselves properly or are characterised by a digestive disorder. "Under the Galenic regime of humours, which imagines all illness as an imbalance among the four nutritive fluids produced by digestion" (p246), ${ }^{6}$ Scotland thus becomes a macro-system suffering from complexional imbalance of digestive origin. The correctness of this diagnosis finds its textual evidence in the dialogue between Macbeth and the Doctor in act 5, scene 3. After being informed of the precarious state of health of his wife, whom he describes as a "mind diseased" by a "rooted sorrow" (note the haunting reappearance of Banquo's "insane root"), Macbeth asks the Doctor for an "oblivious antidote" which can

raze out the written troubles of the brain, [...] Cleanse the stuffed bosom of that perilous stuff Which weighs upon the heart. (act 5, scene 3, lines 44-6)

Then he makes a most strange request:



It is apparent that the patient here is nothing but the body politic, and the urine Macbeth intends to analyse is the one excreted by the State. The inspection of urine was a common diagnostic practice in Renaissance medicine, as suggested, for instance, by traditional iconography, where the doctor is often depicted with a urine flask in his hands. But what kind of pathologies could be diagnosed by urinalysis?

"Urinalysis"-writes David C. Lindberg-"could reveal the state of the liver" (p335). ${ }^{7}$ More generally, it could reveal the state of health (the Galenic complexio) of the organs governing digestion, stomach included. It is clear that Macbeth has already made his own diagnosis: he is sure that the body politic suffers from digestive illness (be it gastric or intestinal). Adequate medical treatments are required to heal the suffering State. But Macbeth's request for medical treatment is astonishingly precise:

\section{What rhubarb, cynne, or what purgative drug Would scour these English hence?}

It is a strange request, first because of its terminological accuracy. Why is Macbeth so accurate in his speech? Why does he mention "rhubarb" and "cynne"? "A large part of medical therapeutics was based on the products of the natural world, and pharmacy, which created medicines from them, was long established as a major division of medicine" (p298). ${ }^{8}$

Herbs are among the chief ingredients of Renaissance medical prescriptions: 17th-century medical handbooks (called consilia), for instance, are full of natural remedies, and among them emetics and laxatives play a central role. What grants them large-scale applicability in a variety of different pathologies is their capacity to remove bad or superfluous humours, which are held to cause complexional imbalance and, therefore, every bodily illness. Nearly all the medical remedies of a century "short of surgery are intended to expel [...] pernicious excess, through purgation or phlebotomy, or to correct a humoral imbalance through ingestion" (p250). ${ }^{6}$ The central role played by the stomach in Renaissance human physiology is underlined here: as many pathologies derive from a complexional imbalance of digestive origins, it is necessary to prescribe "rhubarb" and "cynne", for they both act on the stomach and the bowels. John Gerard, author of one of the most influential herbals of the 17th century, praises the numerous properties of rhubarb: "Rhubarb" - he writes-"is commended by Dioscorides against windnesse, weaknesse of the stomack, and all griefes thereof, convulsions, diseases of the spleene, liver, and kidnies, gripings and inward gnawings of the guts, infirmities of the bladder and chest, swelling about the heart, diseases of the matrix, paine in the huckle bones, spitting of bloud, shortnesse of breath. [...] Besides that it purgeth forth choleric and naughty humors, it removeth stoppings out of the conduits" (p395) (italics mine). ${ }^{9}$

As for cynne, John Gerard writes: "it is a singular purging medicine in many diseases, for all ages and kindes" (p1297). ${ }^{9}$ Such qualities make it an important component of purgative drugs, especially if combined with anise or, precisely, rhubarb: "it may be helped not only by the salgem, but also by other purging things mixed therewith, that is to say with simple medicines, as rubarb." Cynne also "cleaneth the brain, purgeth it, as also the heart, liver, milt, and lungs, causeth a man to looke yong, ingendreth mirth, and taketh away sorrow: it cleareth the sight, and is very good against old fevers and diseases arising of melancholy" (p1298). ${ }^{9}$

These properties make rhurbarb and cynne consistent with our textual-medical analysis, also because the verb "taketh away" synonymically recalls Macbeth's "pluck from the memory a rooted sorrow" (act 5, scene 3, line 42). Macbeth's "sweet oblivious antidote" could reasonably be a cynne-rhubarb decoction or infusion, which "eradicates" pain and "ingendreth mirth". The State, traditionally shaped as a huge body, needs 
purging as well, and cynne and rhubarb can jointly bring it "to a sound and pristine health".

Macbeth is well aware of the prodigious effects of purgative herbs: in fact the purgative drug Macbeth prescribes to Scotland has the power to "scour these English hence" (act 5, scene 3, line 57); in other words, it can pluck out the English troops-a sort of carcinogenic foreign body which prevents the Scottish digestive apparatus from functioning properly. Like a Renaissance practitioner, Macbeth diagnoses a digestive blockage caused by the English, who act as a gallstone that interrupts the vital osmosis between bodily liquids and tissues. Cleansing is, therefore, the most adequate remedy for the congested body politic. Intestinal occlusion seriously threatens the health of the political organic whole, because it prevents food from being transformed into nutrition fluids "that can be dispersed through the blood to the different parts of the body as needed" (p247). ${ }^{6}$ Scotland is, in other words, like many of its inhabitants, a body that is not able to feed itself properly.

But the Doctor consulted by Macbeth is the one who witnessed the outbursts of Lady Macbeth's folly in act 5, scene 1. Moreover, he is the one who declared the inadequacy of traditional medicine (based - as we have seen-on the use of natural remedies such as vegetal laxatives and drugs) with the words, "This disease is beyond my practice" (act 5, scene 1, line 49). Since the patient is the body politic, traditional medicine is of no use and the Doctor cannot rely on it. But an intervention is urgently required. Given the inefficacy of traditional remedies, the Doctor is left uncertain whether to condemn the body politic to certain death or to try a drastic measure: political surgery.

In Shakespeare's time the resolution to undergo surgery was undoubtedly risky, mainly because surgery could offer a very low recovery rate. Moreover, since no effective anaesthetic had been discovered, the human desire to avoid painful medical treatments often made people chose the surgical option. From this point of view, Macbeth's words "I'll fight till from my bones my flash be hacked" (act 5, scene 3, line 32) may reveal his firm resolution to undergo political surgery in the hope that healing could stem from it. The aim of surgery is, however, the same as in traditional medicine: to unblock the body politic congested by a gangrenous foreign body. But surgical instruments are by far more "intrusive" than natural ones: surgery means bodily tearing and fragmentation, and the operation of "razing out" a gallstone amounts to the utmost painful physical profanation.

In Macbeth, surgery has a clear political meaning. The forces marching towards Macbeth at the end of the play do not disdain the most violent form of political surgery. It is significant that political surgery makes its first appearance in the dialogue between Macduff and Malcolm at the end of act 5 . Scotland-these are Malcolm's words-

\section{weeps, it bleeds, each day a new gash}

Is added to her wounds. (act 5, scene 3 , line 153)

Its skin is covered with wounds and sores, and blood does not stop oozing from the open body of the State. It is not by chance, then, that Macduff and Malcolm think of Scotland's liberation as a kind of exorcism, or rather an exorcistic gastric lavage: Piero Camporesi writes that "in the Renaissance the technique of evacuation and the practice of exorcism were so intertwined that they could be thought to be the same" (my translation) (p138). ${ }^{10}$ Scotland-so the argument might run-can recover from illness only after a "purgative" exorcism, which can free it from fiendish possession. This seems to be the subject of Malcolm's appeal: "When shalt thou see thy wholesome days again" (act 4, scene 3, line 105), where the adjective "wholesome" is used in its most literal sense of "beneficial, salutary"11 (in physical terms). The brave men who can free Scotland from evil are like a "purging drug" for the body politic: such is the meaning of Malcolm's

let's make us med'cines of our great revenge

To cure this deadly grief (act 4 , scene 3 , lines $216-7$ ),

or Caithness's

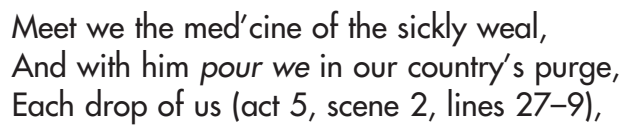

where the tyrannicides are described in terms of roots that, once squeezed, release blood and healing juices. Moreover, when juxtaposing the spectacle of the "bleeding country" with the concrete vision of the "tyrant's head" (act 4, scene 3, line 45), Malcolm reveals that he is thinking of real political surgery as the only remedy that can cure the body politic.

Now Shakespeare's dramatic experiment reveals its darkest sinews: first, he adopts one of the most influential metaphors of society as the main ideological scaffolding of his play; then he moulds it by making constant reference to Renaissance physiology, so as to exploit the figurative potential emerging from the combination of the body politic theory and human physiology; last, he leads the audience to recognise that the functioning of the State is more than simply similar to that of the human body. In Macbeth, the State is a real human body sensu stricto: it gets ill, it bleeds, and surgery is the only remedy to cure it. What is striking is that the surgical removal of the strangling foreign body is more than literally and metaphorically physical: after Macduff's appearance, Macbeth recognises that he himself is the gallstone that must be removed. Macduff, the tyrannicyde, can shout "the time is free" only after plucking the foreign body-Macbeth's physical body-from the entrails of the body politic. So, bodily dismemberment, which follows what has been an authentically exorcising evacuation, coincides with Macbeth's physical death, and the horrific vision of Macbeth's severed head testifies that political liberation is the ultimate result of a terrible, yet real, surgical operation. Once "purged", the body politic can start functioning again; its organs can secrete and absorb vital bodily liquids, and blood can irrigate its limbs. The foreign body has been removed from the congested body politic. Now "the time is free" (act 5, scene 9, line 22), but political surgery has been fatally inaugurated.

Competing interests: None declared.

\section{REFERENCES}

1 Spicci M. The dialectics of self-anatomy: dissection, bloodshed and autoptic visions in Shakespeare's Macbeth. In: Coelsch-Foisner S, eds. Fantastic body transformations in English literature. Salzburg: Heidelberg, 2006:19-30.

2 Salisbury J. Policraticus: L'uomo di governo medievale. Milan: Jaca Book, 1980.

3 Plato, Laws, 628c ff..

4 Cavarero A. Corpo in figure: filosofia e politica della corporeità. Milan: Feltrinelli, 1995.

5 Macbeth. The New Cambridge Shakespeare. Cambridge: Cambridge University Press, 1997

6 Schoenfeldt M. Fables of the belly in early modern Europe. In: Hillmann D, Mazzio C, eds. The body in parts: fantasies of corporeality in early modern Europe. New York-London: Routledge, 1997.

7 Lindberg DC. The beginnings of Western science: the European scientific tradition in philosophical, religious and institutional context, 600 BC to AD 1450. ChicagoLondon: University of Chicago Press, 1992.

8 Conrad L, Neve M, Nutton V, et al. The Western medical tradition $800 B C$ to $A D$ 1800. Cambridge: Cambridge University Press, 1995.

9 Gerard J. The herbal, or general history of the plants, the complete 1633 edition as revised and enlarged by Thomas Johnson. Toronto-London: Dover Publications, 1975.

10 Camporesi P. La carne impassibile. Milan: Il Saggiatore, 1991.

11 Oxford English Dictionary Online. Oxford: Oxford University Press, 2007. http://www.oed.com/ 